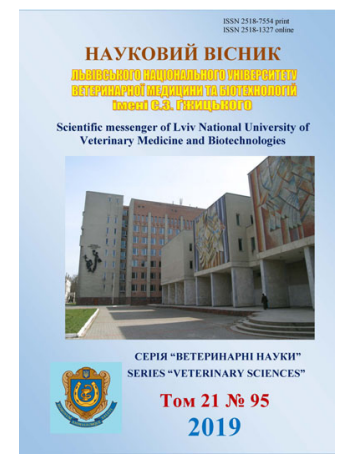

Науковий вісник Дьвівського національного університету ветеринарної медицини та біотехнологій імені С.3. Гжицького. Серія: Ветеринарні науки

Scientific Messenger of Lviv National University of Veterinary Medicine and Biotechnologies. Series: Veterinary sciences

\title{
Chronic toxicity of the Iron (IV) clathrochelate complexes for white rats
}

\author{
V.B. Dukhnitsky ${ }^{1}$, I.M. Derkach ${ }^{1}$, S.S. Derkach ${ }^{1}$, I.O. Fritsky², M.O. Plutenko ${ }^{2}$ \\ ${ }^{1}$ National University of Life and Environmental Sciences of Ukraine, Kyiv, Ukraine \\ ${ }^{2}$ Taras Shevchenko National University of Kyiv, Kyiv, Ukraine
}

Article info

Received 03.09.2019

Received in revised form 01.10 .2019

Accepted 02.10.2019

National University of Life and Environmental Sciences of Ukraine, Heroyiv Oborony Str., 15, Kyiv, 03041, Ukraine.

Tel. $+38-066-772-41-94$

E-mail:irina1215@ukr.net

Taras Shevchenko National University of Kyiv,

Volodymyrska Str., 64 Kyiv, 01601, Ukraine.

Tel.: +38-097-060-82-98

E-mail:plutenkom@gmail.com
Dukhnitsky, V.B., Derkach, I.M., Derkach, S.S., Fritsky, I.O., \& Plutenko, M.O. (2019). Chronic toxicity of the Iron (IV) clathrochelate complexes for white rats. Scientific Messenger of Lviv National University of Veterinary Medicine and Biotechnologies. Series: Veterinary sciences, 21(95), 15-21. doi: 10.32718/nvlvet9503

The article presents the results of studies of chronic toxicity of the Iron in the rare unconventional valence - IV. During long-term use of the Iron(IV) clathrochelate complexes for white rats we have established the dynamics of the body weight of rats, the relative coefficients of mass of the internal organs, the content of hemoglobin and morphological parameters of blood, biochemical parameters of blood serum of animals of this species. The daily drinking of solution of the Iron(IV) clathrochelate complexes at the doses of 500 and $1000 \mathrm{mg} / \mathrm{kg} \mathrm{b}$. w. resulted in a decrease in body weight, an increase in the relative indices of masses of liver and kidney, and a decrease in the relative indices of masses of spleen and heart on $30^{\text {th }}$ day. The hemoglobin content in the blood of rats of the experimental group was less than the control indicator by $3-47 \%(P<0.05)$, which is evidence of inhibition of its synthesis under the influence of the Iron (IV) clathrochelate. Changes in the morphological composition of the blood were characterized by marked leukocytopenia. The use of rats of a solution of the Iron (IV) clathrochelate complexes at doses of 500 and $1000 \mathrm{mg} / \mathrm{kg} \mathrm{b}$. w. caused the development of hypoproteinemia, hypercreatinemia and hyperurinemia. Iron(IV) clathrochelate complexes reduced alaninaminotransferase activity in the serum of rats of both experimental groups by 15-80\% ( $P<0.05)$; aspartataminotransferase activity increased significantly by day 10 and decreased by day 30; the activity of alkaline phosphatase was independent of the doses of the drug during the experimental period. The content of Calcium total, Phosphor inorganic and Iron in the serum of rats of the experimental groups was at the level of indicators in the animals of the control group. Consequently, comprehensive studies of the effects of solution of the Iron (IV) clathrochelate complexes at doses of 500 and $1000 \mathrm{mg} / \mathrm{kg} \mathrm{b}$. w. were performed for the first time with long-term administration to white rats, which revealed the main patterns of metabolic disorders and physiological functions.

Key words: hexahydrazide clathrochelate, toxicology, body weight, morphological parameters of blood, biochemical parameters of blood serum.

\section{Хронічна токсичність клатрохелату Феруму (IV) для білих щурів}

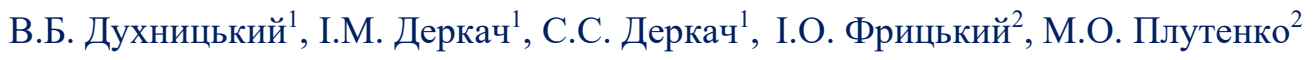 \\ ${ }^{1}$ Національний університет біоресурсів і природокористування Украӥни, м. Київ, Украӥна \\ ${ }^{2}$ Київський національний університет імені Тараса Шевченка, м. Київ, Украйна
}

\footnotetext{
У статті подано результати досліджень хронічної токсичності Феруму в рідкісній нетрадиційній валентності - IV. За умов тривалого застосування клатрохелату Феруму (IV) встановлено динаміку маси тіла щурів, відносних коефіцієнтів маси внутрішніх органів, уміст гемоглобіну та морфологічні показники крові, біохімічні показники сироватки крові тварин даного виду. Щоденне випоювання шурам дослідних груп розчину клатрохелату Феруму (IV) у дозах 500 та 1000 мг/кг м. т. призвело на 30 добу до зменшення маси тіла на 9 та 11\% відповідно, збільшення відносних показників маси печінки та нирок $і$ зменшення відносних показників маси селезінки та серця. Вміст гемоглобіну в крові шурів дослідних груп був меншим від показника контролю на 3-47\% $(P<0,05)$, щзо є свідченням пригнічення його синтезу під впливом клатрохелату Феруму (IV). Зміни морфологічного складу крові
} 
характеризувалися вираженою лейкоцитопенією. Застосування иурам розчину клатрохелату Феруму (IV) у дозах 500 та 1000 мг/кг м. т. спричинило розвиток гіпопротеїнемії, гіперкреатинемії та гіперуринемії. Клатрохелат Феруму (ІV) знижував активність аланінамінотрансферази у сироватиі крові шурів обох дослідних груп на 15-80\% (P<0,05); активність аспартатамінотрансферази вірогідно зростала на 10 добу та була меншою на 30 добу (P < 0,001); активність лужної фосфатази не залежала від доз препарату на період досліджень. Уміст Кальиію загального, Фосфору неорганічного та Феруму у сироватиі крові иурів дослідних груп був на рівні показників у тварин контрольної групи. Отже, вперше виконано комплексні дослідження впливу розчину клатрохелату Феруму (IV) у дозах 500 та 1000 мг/кг м. т. за тривалого застосування на організм білих шурів, щя дало можливість виявити основні закономірності порушень обміну речовин і фізіологічних функиій.

Ключові слова: гексагідразидний клатрохелат, токсикологія, маса тіла, морфологічні показники крові, біохімічні показники сироватки крові.

\section{Вступ}

Потреба України у продукції тваринництва передбачає розвиток галузі свинарства. У цьому разі стан здоров'я тварин визначає ветеринарне благополуччя країни та відповідно якість і безпечність продуктів тваринного походження. Отже, одним з факторів, що забезпечує сталий розвиток свинарства, $є$ підтримка на високому рівні здоров'я свиней.

Ветеринарні превентивні технології забезпечення здоров'я тварин даного виду $є$ ключовими у веденні свинарства. Успіх їх реалізації багато в чому залежить від наукового обгрунтування комплексу заходів, які не можуть бути здійснені без знання різновекторних особливостей даної галузі тваринництва. Незважаючи на правильно означену й організовану систему заходів профілактики, все ж таки існують ризики, які необхідно мінімізувати.

Численні повідомлення у вітчизняній та зарубіжній літературі свідчать про те, що серед неінфекційних хвороб свиней, що виявляють у сучасних свинарських господарствах як в Україні, так і в світі найбільшого розповсюдження набули ферумдефіцитні анемії (Cui et al., 2018; Kim et al., 2018), що завдають значних економічних збитків. Одним з перспективних шляхів їхньої профілактики є застосування протианемічних лікарських засобів. Останні повинні бути високоефективними, екологічно безпечними, економічно доступними та зручними у практичному застосуванні. Ця проблема носить глобальний характер у практиці ветеринарної медицини.

Ефективність багатьох наявних ферумовмісних препаратів є доведеною як науковими дослідженнями, так і практичним досвідом (Lipiński et al., 2010; Maes et al., 2011; Streyl et al., 2015; Cui et al., 2018; Todoriuk et al., 2018). Комплекс Феруму (III) гідроксиду з низькомолекулярним декстраном, що найчастіше є діючою речовиною сучасних протианемічних лікарських засобах для тварин (Derkach, 2017), стимулює кровотворну систему, підвищує рівень гемоглобіну в крові, збільшує кількість еритроцитів, поповнює нестачу Феруму в організмі, підвищує продуктивність сільськогосподарських тварин. Відповідно за комбінацій Феруму з іншими речовинами комплексні препарати мають ширший діапазон фармакологічної дії. Так, ціанокобаламін, який найчастіше входить до складу таких препаратів, стимулює процеси кровотворення, активізує обмін ліпідів, біосинтез метіоніну, метаболічні процеси та $є$ необхідним для синтезу ДНК.
Проте ферумовмісні засоби мають певні недоліки. Зокрема, наявні у ветеринарній медицині лікарські засоби на основі ферумдектранових комплексів застосовують поросятам віком 2-3 доби, в основному у формі внутрішньом'язових ін'єкцій. Це своєю чергою $\epsilon$ стресом у перші доби життя тварин та відповідно призводить до значних витрат енергії новонародженого організму, зниження приросту маси тіла тощо. $€$ деякі особливості застосування цих препаратів: у місці ін'єкції шкіру рекомендують зміщувати убік, щоб препарат не витікав; тут після введення розчину спостерігається пігментація тканин. У зимовий період препарати перед використанням необхідно підігрівати до температури $37-38^{\circ} \mathrm{C}$.

До того ж існуючі ферумовмісні лікарські засоби проявляють побічну дію. Свині окремих порід є генетично чутливими до препаратів Феруму, а за дефіциту в організмі вітаміну Е та/або Селену можлива загибель поросят. Протипоказаннями до застосування є: недостатність в організмі вітаміну Е; діарея; комбінація з тетрациклінами; змішування з іншими ветеринарними препаратами тощо.

Останніми роками вивченню властивостей сполук Феруму (IV) присвячено багато праць (Gloves et al., 2006; England et al., 2014; Tomyn et al., 2017), оскільки рідкісний нетрадиційний ступінь окиснення +4 реалізується в каталітичних циклах багатьох ферумовмісних ферментів, але зовсім не досліджувалась біологічна активність речовин даного типу, зокрема, не висвітлено його вплив на організм свиней, фармакокінетику та фармакодинаміку. Перед проведенням таких експериментів обов'язковими є доклінічні дослідження на лабораторних тваринах (Kotsiumbas, 2006).

Нами раніше вже повідомлялося про вивчення впливу клатрохелату Феруму (IV) на основі макробіциклічного ліганду гексагідразидного типу на організм білих мишей (Dukhnitsky et al., 2018) та дослідження його кумулятивних властивостей в організмі щурів (Dukhnitsky et al., 2019).

Дослідження хронічної токсичності лікарських засобів $є$ основним для встановлення можливих побічних та віддалених наслідків, гранично допустимих рівнів, а також впливу на довкілля (Kotsiumbas, 2006). Дослідження хронічної токсичності сполук Феруму (IV) в Україні та світі проводяться вперше, тому мають важливе теоретичне значення для науки та практичну значущість для ветеринарної медицини загалом у плані збереження поголів'я свиней і відповідно отримання від них продукції високої біологічної цінності та санітарної якості. 
Метою нашої роботи було дослідити вплив на організм білих щурів гексагідразидного клатрохелату Феруму (IV) за багаторазового застосування.

\section{Матеріал і методи досліджень}

Дослідження хронічної токсичності клатрохелату Феруму(IV) $\mathrm{Na}_{2}[\mathrm{Fe}(\mathrm{L}-6 \mathrm{H})] \cdot 2 \mathrm{H}_{2} \mathrm{O}$ (L - макробіциклічний гексагідразидний ліганд) проводили на щурах, масою тіла 200-300 г, сформованих у три групи по 15 тварин у кожній: тварини I групи (контроль) - отримували воду; щурам II групи випоювали розчин клатрохелату Феруму (IV) із розрахунку 500 мг/кг маси тіла (1/10 DL50 досліджуваної сполуки); щурам III групи випоювали розчин клатрохелату Феруму (IV) iз розрахунку 1000 мг/кг маси тіла (1/5 DL 50 досліджуваної сполуки).

Тварин утримували в умовах віварію факультету ветеринарної медицини НУБіП України, зі сталою температурою повітря та вологістю у приміщеннях. Годівля щурів передбачала стандартний раціон 3 постійним доступом до води / водного розчину клатрохелату Феруму (IV). Перед початком досліду тварин утримували в адаптаційному періоді 10 діб. Відхилень у поведінкових реакціях щурів як дослідної, так і контрольної груп не спостерігали.

Впродовж усього періоду експерименту за тваринами здійснювали спостереження та враховували загальний стан, характер і ступінь активності, координацію руху, наявність тремору, судом, парезів, паралічів, виділень з очей, носа, зміну кольору шкіри та апетиту. Щурів також зважували та відмічали зміни їх маси тіла.
Для визначення відносних коефіцієнтів маси внутрішніх органів, проведення морфологічних та біохімічних досліджень на 10, 20, і 30 доби експерименту, за умов легкого ефірного наркозу, проводили евтаназію 5 тварин 3 кожної групи. Відбір проб біологічного матеріалу проводили з урахуванням "Загальних етичних принципів експериментів на тваринах" (Україна, 2001) та згідно з положеннями Європейської конвенції щодо захисту хребетних тварин (Stratsburg: Counsil of Europe 18.03.1986). Визначення морфологічних та біохімічних показників крові та сироватки крові проводили загальноприйнятими методами. Отримані результати були оброблені методом варіаційної статистики 3 використанням комп'ютерної програми Excel, результати середніх значень вважали статистично вірогідними за $\mathrm{P} \leq 0,05$.

\section{Результати та їх обговорення}

Проведеними експериментальними дослідженнями встановлено, що випоювання щурів розчином Феруму (IV) у формі клатрохелату в дозах 500 мг/кг м. т. та 1000 мг/кг м. т. не спричиняло видимих ознак інтоксикації та загибелі тварин.

На 10 і 20 доби спостереження піддослідні тварини зберігали апетит, поведінкові реакції були адекватними та відображали нормальний функціональний стан центральної нервової системи. На 30 добу виявляли дещо пригнічений стан у щурів дослідних груп. Волосся втрачало блиск, було скуйовдженим, фекалії були м'якої консистенції, маса тіла зменшувалася порівняно з показниками тварин контрольної групи.

Показники маси тіла щурів за випоювання розчину клатрохелату Феруму (IV) подано у таблиці 1.

\section{Таблиця 1}

Динаміка маси тіла щурів за тривалого застосування розчину клатрохелату Феруму (IV) $(\mathrm{M} \pm \mathrm{m}, \mathrm{n}=5)$

\begin{tabular}{lclll}
\hline \multirow{2}{*}{ Група } & \multicolumn{4}{c}{ Маса тіла, г } \\
\cline { 2 - 5 } тварин & На початок досліду & На 10 добу & На 20 добу & На 30 добу \\
\hline I Контрольна & $289,6 \pm 2,5$ & $293,2 \pm 3,26$ & $302,2 \pm 4,63$ & $328,8 \pm 6,37$ \\
II Дослідна & $291,6 \pm 1,36$ & $298,6 \pm 3,71$ & $301,4 \pm 3,11$ & $300,2 \pm 4,03 * *$ \\
III Дослідна & $290,2 \pm 0,97$ & $298,8 \pm 4,32$ & $303,4 \pm 5,06$ & $291,8 \pm 6,65^{* *}$ \\
\hline
\end{tabular}

Примітка: ступінь вірогідності - ** - $\mathrm{P}<0,01$

Встановлено, що маса тіла щурів дослідних груп була дещо більшою на 10 добу, не відрізнялась від показника у тварин контрольної групи на 20 добу, тимчасом як на 30 добу вірогідно зменшувалася майже на 9\% у щурів, які отримували клатрохелат Феруму (IV) в дозі 500 мг/кг м. т., та на $11 \%$ у щурів, які отримували клатрохелат Феруму (IV) в дозі 1000 мг/кг м. т. (табл. 1).

Окрім зміни маси тіла важливими показниками, що відображають рівень метаболічних процесів в організмі тварин за їх інтоксикації, є зміни маси окремих органів. Коефіцієнти маси внутрішніх органів щурів за визначення хронічної токсичності клатрохелату Феруму (IV) наведено у таблиці 2.

За аналізу коефіцієнтів маси внутрішніх органів щурів на 10 добу виявляли достовірне збільшення маси печінки і нирок та зменшення маси серця і селезінки у тварин дослідних груп, причому за дози 1000 мг/кг м. т. (III дослідна група) ці зміни є вираженішими, ніж за дози 500 мг/кг м. т. На 20 добу встановлено лише вірогідне зменшення відносного коефіцієнту маси серця у щурів обох дослідних груп та збільшення відносного коефіцієнту нирок у тварин III дослідної групи. 
Таблиця 2

Відносні коефіцієнти маси внутрішніх органів щурів за тривалого застосування розчину клатрохелату Феруму (IV) $(\mathrm{M} \pm \mathrm{m}, \mathrm{n}=5)$

\begin{tabular}{|c|c|c|c|c|}
\hline \multirow{2}{*}{ Орган } & \multirow{2}{*}{ Група тварин } & \multicolumn{3}{|c|}{ Час проведення досліду } \\
\hline & & 10 доба & 20 доба & 30 доба \\
\hline \multirow{3}{*}{ Печінка } & I Контрольна & $3,3 \pm 0,16$ & $3,4 \pm 0,17$ & $3,5 \pm 0,12$ \\
\hline & II Дослідна & $3,6 \pm 0,05$ & $3,7 \pm 0,17$ & $4,6 \pm 0,05 * * *$ \\
\hline & III Дослідна & $3,8 \pm 0,06^{*}$ & $3,9 \pm 0,06$ & $4,7 \pm 0,08 * * *$ \\
\hline \multirow{3}{*}{ Серце } & I Контрольна & $0,4 \pm 0,01$ & $0,4 \pm 0,01$ & $0,5 \pm 0,01$ \\
\hline & II Дослідна & $0,3 \pm 0,03$ & $0,3 \pm 0,02 * *$ & $0,4 \pm 0,02$ \\
\hline & III Дослідна & $0,3 \pm 0,02 * *$ & $0,2 \pm 0,02 * * *$ & $0,3 \pm 0,02 * *$ \\
\hline \multirow{3}{*}{ Нирки } & I Контрольна & $0,7 \pm 0,03$ & $0,8 \pm 0,03$ & $0,8 \pm 0,03$ \\
\hline & II Дослідна & $0,8 \pm 0,03$ & $0,8 \pm 0,02$ & $0,9 \pm 0,02$ \\
\hline & III Дослідна & $1,0 \pm 0,05 * * *$ & $1,1 \pm 0,06^{* *}$ & $1,0 \pm 0,03^{* * *}$ \\
\hline \multirow{3}{*}{ Селезінка } & I Контрольна & $0,5 \pm 0,02$ & $0,5 \pm 0,03$ & $0,5 \pm 0,02$ \\
\hline & II Дослідна & $0,4 \pm 0,03$ & $0,4 \pm 0,06$ & $0,4 \pm 0,05$ \\
\hline & III Дослідна & $0,3 \pm 0,02 * * *$ & $0,3 \pm 0,06$ & $0,3 \pm 0,03 * *$ \\
\hline
\end{tabular}

Зміни відносних коефіцієнтів маси внутрішніх органів щурів дослідних груп на 30 добу характеризувалися збільшенням маси печінки на $31 \%$ (Р $<0,001)$ (II дослідна група) і на 34\% (Р < 0,001) (III дослідна група) та нирок на $13 \%$ (II дослідна група) і на 25\% (P < 0,001) (III дослідна група). Відносні коефіцієнти маси серця і селезінки були меншими на 20\% у щурів II дослідної групи і на 40\% (P < 0,01) - у щурів III дослідної групи порівняно 3 показниками у тварин контрольної групи, що свідчить про надмірне навантаження на ці органи.

На 10 добу уміст шлунка щурів обох дослідних груп був зеленого забарвлення. Слизова оболонка без видимих ознак запалення. На 20 добу слизова оболонка шлунка у щурів обох дослідних груп була темночервоного кольору, а у щурів III групи 3 ознаками некрозу. На 30 добу слизова оболонка шлунка була нерівномірно забарвленою, іiі кардіальна частина 3 синювато-зеленуватим відтінком, пілорична частина 3 синім відтінком. Кровоносні судини з боку серозної оболонки розширені, переповнені кров'ю. У щурів III групи вищеописані ознаки були вираженішими, а слизова оболонка тонкою.

Результати дослідження морфологічних показників у крові наведено в таблиці 3.

Таблиця 3

Уміст гемоглобіну та морфологічні показники крові щурів за тривалого застосування розчину клатрохелату Феруму (IV) $(\mathrm{M} \pm \mathrm{m}, \mathrm{n}=5)$

\begin{tabular}{|c|c|c|c|c|}
\hline \multirow{2}{*}{ Показник } & \multirow{2}{*}{ Група тварин } & \multicolumn{3}{|c|}{ Час проведення досліду } \\
\hline & & 10 доба & 20 доба & 30 доба \\
\hline \multirow{3}{*}{ Гемоглобін, г/л } & I Контрольна & $123,8 \pm 1,62$ & $128,6 \pm 2,27$ & $131,8 \pm 1,13$ \\
\hline & II Дослідна & $118,4 \pm 0,81^{*}$ & $117,64 \pm 0,86^{* *}$ & $127,8 \pm 0,74^{*}$ \\
\hline & III Дослідна & $82,7 \pm 1,81 * * *$ & $68,28 \pm 1,2 * * *$ & $97,6 \pm 1,82 * * *$ \\
\hline \multirow{3}{*}{$\begin{array}{l}\text { Еритроцити, } \\
\text { Т/л }\end{array}$} & I Контрольна & $5,7 \pm 0,05$ & $6,0 \pm 0,19$ & $6,4 \pm 0,21$ \\
\hline & II Дослідна & $5,2 \pm 0,12 * *$ & $5,1 \pm 0,24^{*}$ & $6,9 \pm 0,32$ \\
\hline & III Дослідна & $6,8 \pm 0,06 * * *$ & $6,2 \pm 0,23$ & $7,1 \pm 0,25$ \\
\hline \multirow{3}{*}{ Гематокрит, \% } & I Контрольна & $35,1 \pm 1,39$ & $37,9 \pm 1,88$ & $40,5 \pm 1,88$ \\
\hline & II Дослідна & $33,3 \pm 0,57$ & $35,4 \pm 0,31^{*}$ & $38,4 \pm 0,94$ \\
\hline & III Дослідна & $40,5 \pm 0,57 *$ & $40,7 \pm 0,78$ & $42,7 \pm 1,09$ \\
\hline \multirow{3}{*}{ Лейкоцити, Г/л } & I Контрольна & $16,5 \pm 0,29$ & $18,2 \pm 0,66$ & $18,0 \pm 0,66$ \\
\hline & II Дослідна & $17,6 \pm 0,56$ & $11,5 \pm 0,59 * * *$ & $17,0 \pm 0,66$ \\
\hline & III Дослідна & $14,5 \pm 0,68^{*}$ & $8,4 \pm 0,43^{* * *}$ & $14,9 \pm 0,36^{* *}$ \\
\hline
\end{tabular}

Примітка: ступінь вірогідності - * - $\mathrm{P}<0,05, * *-\mathrm{P}<0,01, * * *-\mathrm{P}<0,001$

Уміст гемоглобіну у крові щурів II та III дослідних груп був вірогідно меншим від показника тварин контрольної групи на 10 добу на 5 та 33\% відповідно; на 20 добу - на 9 та 47\%; на 30 добу - на 3 та 26\% відповідно.

Кількість еритроцитів у крові щурів контрольної та дослідної груп на 10 і 20 доби спостереження була в межах фізіологічних значень. На 30 добу спостері- гали незначну тенденцію до збільшення кількості еритроцитів у крові щурів дослідних груп. Показник гематокриту у тварин контрольної та дослідних груп протягом 30 діб був у межах фізіологічних значень.

Під впливом розчину клатрохелату Феруму (IV) кількість лейкоцитів у крові щурів дослідних груп була меншою, ніж у контролі впродовж усього періоду досліджень, що є свідченням пригнічення лейкоци- 
топоезу. Так, на 10 добу їх кількість у крові тварин III дослідної групи була меншою від показника у контролі на $12 \%(\mathrm{P}<0,05)$. На 20 добу їх кількість у крові тварин II дослідної групи становила 63\%, у крові III дослідної групи - 46\% порівняно з показниками у щурів контрольної групи (Р < 0,001). На 30 добу кількість лейкоцитів у крові щурів II дослідної групи не відрізнялась від показника у контролі, тимчасом як у тварин III дослідної групи була меншою на $17 \%$ $(\mathrm{P}<0,01)$.

Серед біохімічних показників сироватки крові щурів найбільших змін зазнавали показники обміну білків та небілкових сполук нітрогену, активність ензимів та уміст глюкози (табл. 4).

\section{Таблиця 4}

Біохімічні показники сироватки крові щурів за тривалого застосування розчину клатрохелату Феруму (IV) $(\mathrm{M} \pm \mathrm{m}, \mathrm{n}=5)$

\begin{tabular}{|c|c|c|c|c|}
\hline \multirow{2}{*}{ Показник } & & \multicolumn{3}{|c|}{ Група тварин } \\
\hline & & 10 доба & 20 доба & 30 доба \\
\hline \multirow{3}{*}{$\begin{array}{l}\text { Протеїн загальний, } \\
\text { г/л }\end{array}$} & I Контрольна & $65,4 \pm 1,62$ & $67,0 \pm 0,98$ & $66,6 \pm 0,61$ \\
\hline & II Дослідна & $60,6 \pm 0,43^{*}$ & $62,4 \pm 1,36^{*}$ & $66,0 \pm 0,89$ \\
\hline & III Дослідна & $66,7 \pm 0,83$ & $64,1 \pm 0,82^{*}$ & $65,3 \pm 0,79$ \\
\hline \multirow{3}{*}{ Альбуміни, \% } & I Контрольна & $48,6 \pm 0,51$ & $50,4 \pm 0,78$ & $49,9 \pm 0,94$ \\
\hline & II Дослідна & $35,3 \pm 0,97 * * *$ & $32,9 \pm 1,23 * * *$ & $27,1 \pm 1,33 * * *$ \\
\hline & III Дослідна & $33,2 \pm 1,39 * * *$ & $25,3 \pm 0,86^{* * *}$ & $23,1 \pm 1,37 * * *$ \\
\hline \multirow{3}{*}{ Глюкоза, ммоль/л } & I Контрольна & $6,9 \pm 0,34$ & $7,0 \pm 0,29$ & $7,4 \pm 0,16$ \\
\hline & II Дослідна & $16,2 \pm 0,36^{* * *}$ & $16,9 \pm 0,46 * * *$ & $10,3 \pm 0,38 * * *$ \\
\hline & III Дослідна & $8,3 \pm 0,44^{*}$ & $6,7 \pm 0,21$ & $6,5 \pm 0,39$ \\
\hline \multirow{3}{*}{$\begin{array}{l}\text { АлАТ, } \\
\text { ммоль/(год•л) }\end{array}$} & I Контрольна & $0,5 \pm 0,03$ & $0,5 \pm 0,03$ & $0,4 \pm 0,03$ \\
\hline & II Дослідна & $0,3 \pm 0,03^{*}$ & $0,4 \pm 0,04$ & $0,3 \pm 0,03^{*}$ \\
\hline & III Дослідна & $0,1 \pm 0,01 * * *$ & $0,3 \pm 0,04^{*}$ & $0,2 \pm 0,02 * * *$ \\
\hline \multirow{3}{*}{$\begin{array}{l}\text { АсАТ, } \\
\text { ммоль/(год•л) }\end{array}$} & I Контрольна & $0,9 \pm 0,03$ & $0,8 \pm 0,04$ & $0,9 \pm 0,02$ \\
\hline & II Дослідна & $1,2 \pm 0,09 *$ & $0,9 \pm 0,07$ & $0,8 \pm 0,03 * * *$ \\
\hline & III Дослідна & $1,3 \pm 0,13^{*}$ & $0,5 \pm 0,03 * * *$ & $0,7 \pm 0,03 * * *$ \\
\hline \multirow{3}{*}{ ЛФ, ммоль/(год•л) } & I Контрольна & $22,0 \pm 0,71$ & $23,2 \pm 1,88$ & $26,4 \pm 1,48$ \\
\hline & II Дослідна & $26,6 \pm 2,22$ & $29,0 \pm 1,41^{*}$ & $32,1 \pm 1,89^{*}$ \\
\hline & III Дослідна & $21,7 \pm 1,28$ & $24,5 \pm 1,30$ & $13,8 \pm 2,29 * *$ \\
\hline \multirow{3}{*}{$\begin{array}{l}\text { Креатинін, } \\
\text { мкмоль/л }\end{array}$} & I Контрольна & $65,2 \pm 1,38$ & $67,0 \pm 0,49$ & $69,5 \pm 0,33$ \\
\hline & II Дослідна & $89,4 \pm 1,16^{* * *}$ & $75,2 \pm 1,36^{* *}$ & $69,9 \pm 1,21$ \\
\hline & III Дослідна & $151,2 \pm 1,07 * * *$ & $166,7 \pm 2,20 * * *$ & $146,0 \pm 1,76^{* * *}$ \\
\hline \multirow{3}{*}{$\begin{array}{l}\text { Сечова кислота, } \\
\text { ммоль/л }\end{array}$} & I Контрольна & $68,4 \pm 0,75$ & $69,1 \pm 0,71$ & $70,5 \pm 0,74$ \\
\hline & II Дослідна & $65,7 \pm 0,76^{*}$ & $85,3 \pm 0,46^{* * *}$ & $112,6 \pm 4,08 * * *$ \\
\hline & III Дослідна & $64,8 \pm 0,26 * *$ & $93,1 \pm 0,41 * * *$ & $125,7 \pm 3,14 * * *$ \\
\hline \multirow{3}{*}{$\begin{array}{l}\text { Кальцій загальний, } \\
\text { ммоль/л }\end{array}$} & I Контрольна & $3,0 \pm 0,15$ & $2,7 \pm 0,20$ & $2,4 \pm 0,23$ \\
\hline & II Дослідна & $3,2 \pm 0,33$ & $2,8 \pm 0,12$ & $2,3 \pm 0,22$ \\
\hline & III Дослідна & $2,6 \pm 0,19$ & $2,1 \pm 0,13^{*}$ & $2,2 \pm 0,13$ \\
\hline \multirow{3}{*}{$\begin{array}{l}\text { Фосфор неор- } \\
\text { ганічний, ммоль/л }\end{array}$} & I Контрольна & $2,3 \pm 0,16$ & $2,6 \pm 0,16$ & $2,2 \pm 0,15$ \\
\hline & II Дослідна & $3,0 \pm 0,11 * *$ & $2,4 \pm 0,18$ & $2,3 \pm 0,22$ \\
\hline & III Дослідна & $2,2 \pm 0,07$ & $2,9 \pm 0,11$ & $2,6 \pm 0,20$ \\
\hline \multirow{3}{*}{ Ферум, ммоль/л } & I Контрольна & $0,036 \pm 0,0017$ & $0,035 \pm 0,0019$ & $0,034 \pm 0,0012$ \\
\hline & II Дослідна & $0,035 \pm 0,0017$ & $0,036 \pm 0,0011$ & $0,035 \pm 0,0016$ \\
\hline & III Дослідна & $0,038 \pm 0,0013$ & $0,035 \pm 0,0013$ & $0,035 \pm 0,0010$ \\
\hline
\end{tabular}

Примітка: ступінь вірогідності $-*-\mathrm{P}<0,05, * *-\mathrm{P}<0,01, * * *-\mathrm{P}<0,001$

Білки виконують численні функції: підтримують постійність онкотичного тиску, величину рН крові та рівень катіонів у ній, відіграють важливу роль у формуванні імунітету, комплексів із вуглеводами, ліпідами, гормонами та іншими речовинами.

Як видно із даних наведених у таблиці 4, уміст протеїну загального вірогідно зменшувався в сироватці крові щурів II дослідної групи (доза клатрохелату Феруму (IV) 500 мг/кг м. т.) уже через 10 діб, а через 20 діб - гіпопротеїнемія була встановлена у щурів обох дослідних груп (Р <0,05). На 30 добу вміст протеїну загального у сироватці крові тварин контрольної та дослідної груп був на однаковому рівні.
Під впливом клатрохелату Феруму (IV) у тварин дослідних груп розвивалась стійка гіпоальбумінемія, ступінь вираженості якої залежала від дози досліджуваної речовини. Так, у сироватці крові щурів II дослідної групи (доза клатрохелату Феруму (IV) 500 мг/кг м. т.) уміст альбумінів на 10 добу був меншим майже в 1,4 разу $(\mathrm{P}<0,001)$; на 20 добу - в 1,5 разу $(\mathrm{P}<0,001)$; на 30 добу $-1,8$ разу $(\mathrm{P}<0,001)$ від показників у тварин контрольної групи. Уміст альбумінів у сироватці крові щурів III дослідної групи (доза клатрохелату Феруму (IV) 1000 мг/кг м. т.) був меншим від показника контролю у $1,5,1,9$ та 2,2 разу $(\mathrm{P}<0,001)$ відповідно. 
Застосування клатрохелату Феруму (IV) спричинило стійке підвищення рівня глюкози у сироватці крові щурів II дослідної групи. Так, на 10 добу іiі рівень перевищував показник контролю у 2,3 раза, на 20 добу - у 2,4 раза, на 30 добу - в 1,4 (P < 0,001). У сироватці крові щурів III дослідної групи рівень глюкози був вищим від показника контролю лише на 10 добу $(\mathrm{P}<0,05)$ (табл. 4).

Ензимам належить вирішальна роль у забезпеченні нормального обміну речовин, що має визначальне значення для підтримання гомеостазу.

Згідно 3 результатами наших досліджень активність АлАТ у сироватці крові щурів дослідних груп знижувалась, що, на нашу думку, зумовлено гіпопротеїнемією. Так, у щурів II дослідної групи активність АлАТ на 10 добу була меншою від показника контролю на 40\%, на 20 добу - на 20\%, на 30 добу - на 15\% $(\mathrm{P}<0,05)$. У щурів III дослідної групи активнісь АлАТ в сироватці крові була меншою, ніж у контролі на 80, 40 та 50\% відповідно за вірогідної різниці.

Активність АсАТ у сироватці крові тварин II та III дослідних груп вірогідно зростала на 10 добу, тимчасом як у наступні періоди знижувалася і становила на 30 добу 88 та 77\% від показника у щурів контрольної групи $(\mathrm{P}<0,001)$.

Активність ЛФ у сироватці крові щурів дослідних груп не зазнавала суттєвих змін через 10 діб після застосування клатрохелату Феруму (IV). Через 20 діб ii активність у сироватці крові тварин II дослідної групи була більшою, ніж у контролі, на 25\% (P < 0,05), а через 30 діб - на 21\% (Р <0,05). У тварин III дослідної групи активність ЛФ у ці періоди досліджень знижувалась, а через 30 діб становила лише $52 \%$ від показника щурів контрольної групи $(\mathrm{P}<0,01)$.

Суттєвих змін під впливом клатрохелату Феруму (IV) зазнавали показники креатиніну та сечової кислоти. Так, на 10 добу після застосування досліджуваного препарату вміст креатиніну у сироватці крові щурів II дослідної групи був більшим від показника у тварин контрольної групи майже в 1,8 разу ( $<<0,001)$; через 20 діб - в 1,1 разу $(\mathrm{P}<0,01)$, через 30 діб - не відрізнявся від показника контролю. У щурів III дослідної групи (доза клатрохелату Феруму (IV) 1000 мг/кг м. т.) уміст креатиніну у сироватці крові був більшим від показників контролю відповідно у 2,3, 2,5 та 2,1 разу ( $\mathrm{P}<0,001)$.

Рівень сечової кислоти у сироватці крові щурів обох дослідних груп на 10 добу був дещо меншим, ніж у контролі, а через 20 діб зростав та перевищував показник контролю на $21 \%$ (P < 0,001) у щурів II дослідної групи та на 34\% (P < 0,001) у щурів III дослідної групи. На 30 добу вміст сечової кисоти у сироватці крові тварин II дослідної групи був більшим, ніж у контролі, на 60\% (P <0,001), у тварин III дослідної групи - на 78\% (P <0,001).

Вважаємо, що основними причинами зростання вмісту небілкових сполук нітрогену (креатинін, сечова кислота) у сироватці крові щурів дослідних груп $є$ порушення всмоктування амінокислот у кишечнику, посилення їх розкладу та утворення аміаку, який знешкоджується шляхом утворення сечовини та сечової кислоти. Цілком можливим $є$ порушення функції нирок, зумовлене тривалим надходженням клатрохелату Феруму (IV), зменшенням фільтраційної здатності ниркових клубочків, що призводить до затримання виділення сечової кислоти та креатиніну.

Уміст Кальцію загального, Фосфору неорганічного та Феруму в сироватці крові щурів дослідних груп був на рівні показників у тварин контрольної групи.

\section{Висновки}

Відповідно до поставленої мети, уперше виконано комплексні дослідження впливу розчину клатрохелату Феруму (IV) у дозах 500 та 1000 мг/кг м. т. за тривалого застосування на організм білих щурів, що дало можливість виявити основні закономірності порушень обміну речовин і фізіологічних функцій.

Щоденне випоювання щурам дослідних груп розчину клатрохелату Феруму (IV) у дозах 500 та 1000 мг/кг м. т. призвело на 30 добу до зменшення маси тіла на 9 та 11\% відповідно, збільшення відносного показника маси печінки на 31 та 34\% відповідно; нирок - на 13 та 25\%. Відносні показники маси селезінки і серця були меншими на 20 і 40\% відповідно від показників щурів контрольної групи за вірогідної різниці.

Вміст гемоглобіну у крові щурів дослідних груп був меншим від показника контролю на 3-47\% $(\mathrm{P}<0,05)$, що є свідченням пригнічення його синтезу під впливом клатрохелату Феруму (IV) у вказаних дозах. Зміни морфологічного складу крові характеризувалися вираженою лейкоцитопенією.

Застосування щурам розчину клатрохелату Феруму (IV) у дозах 500 та 1000 мг/кг м. т. спричинило розвиток гіпопротеїнемії, а вміст альбумінів у сироватці крові щурів був меншим від показника у тварин контрольної групи в 1,4-2,2 разу (Р < 0,001). Рівень глюкози вірогідно зростав лише у щурів II дослідної групи (доза клатрохелату Феруму (IV) 500 мг/кг м. т.).

Випоювання щурам дослідних груп розчину клатрохелату Феруму (IV) у дозах 500 та 1000 мг/кг призвело до вірогідного збільшення рівня креатиніну (гіперкреатинемія) та сечової кислоти (гіперуринемія), що засвідчує про зменшення фільтраційної здатності ниркових клубочків.

Клатрохелат Феруму(IV) спричиняв зниження активності аланінамінотрансферази у сироватці крові щурів обох дослідних груп на 15-80\% (P < 0,05); активність аспартатамінотрансферази вірогідно зростала на 10 добу та була меншою на 30 добу (P < 0,001); активність лужної фосфатази не залежала від доз препарату на період досліджень.

Перспективи подальших досліджень. Оцінка мікроскопічної структури внутрішніх органів щурів за вивчення хронічної токсичності клатрохелату Ферумy(IV). 


\section{References}

Dukhnitsky, V.B., Derkach, I.M., Plutenko, M.O., Fritsky, I.O., \& Derkach, S.S. (2018). Vyznachennja parametriv gostroi toksychnosti ferumu (IV) na bilyh myshah. Ukrainian Journal of Ecology, 8(2), 308-312. doi: 10.15421/2018 343 (in Ukrainian).

Dukhnitsky, V.B., Derkach, I.M., Plutenko, M.O., Fritsky, I.O., \& Derkach, S.S. (2019). Cumulative properties of Iron(IV) clathrochelate in rats. Visnyk PDAA, 2, 238-246.

Derkach, I. (2017). Suchasni tendencii na vitchyznjanomu rynku ferumvmisnyh preparativ dlja tvaryn. Naukovyj visnyk Lvivskogo nacionalnogo universytetu veterynarnoi medycyny ta biotehnologij imeni S.Z. Gzhyckogo, 19(78), 23-25. doi: 10.15421/nvlvet7805 (in Ukrainian).

Commission of the European Communities: Council Directive of 18 December 1986 on the Lows, regulating the Application of Principles of Good Laboratory Practice and the Verification of Their Applications for Tests on Chemical Substances (87/18/EEC) (1991). The Rules Governing Medicinal Products in the European Community, 1, 145-146.

Cui, J., Li, Y., Yu, P., Zhan, Q., Wang, J., Chi, Y., \& Wang, P. (2018). A novel low molecular weight Enteromorpha polysaccharide-iron (III) complex and its effect on rats with iron deficiency anemia (IDA). International journal of biological macromolecules, 108, 412-418. doi: 10.1016/j.ijbiomac.2017.12.033.

England, J. Bigelow, O., Katherine, M., Heuvelen, V., Farquhar, E., Martinho, M., Meier, K., Frisch, J., Münck, E., \& Que, L. (2014). An ultra-stable oxoiron (IV) complex and its blue conjugate base. Chemical Science, 3, 1204-1215. doi: 10.1039/C3SC52755G.

Groves, J.T. (2006). High-valent iron in chemical and biological oxidations. Journal of Inorganic Biochemistry, 100(4), 434-447. doi: 10.1016/j.jinorgbio.2006.01.012
Kim, J.C., Wilcock, P., \& Bedford, M.R. (2018). Iron status of piglets and impact of phytase superdosing on iron physiology: A review. Animal Feed Science and Technology, 235, 8-14. doi: 10.1016/j.anifeedsci.2017.11.001.

Kotsiumbas, I.Ya. (2006). Doklinichni doslidzhennja veterynarnyh likars'kyh zasobiv. L'viv. Triada pljus (in Ukrainian).

Lipiński, P., Starzyński, R., Canonne-Hergaux, F., Tudek, B., Oliński, R., Kowalczyk, P., Dziaman, T., Thibaudeau, O., Gralak, M.A., Smuda, E., Woliński, J., Usińska, A., \& Zabielski, R. (2010). Benefits and Risks of Iron Supplementation in Anemic Neonatal Pigs. American journal of hematology, 177(3), 12331243. doi: 10.2353/ajpath.2010.091020.

Maes, D., Steyaert, M., Vanderhaeghe, C., López Rodríguez, A., de Jong, E., Del Pozo Sacristán, R., Vangroenweghe, F., \& Dewulf, J. (2011). Comparison of oral versus parenteral iron supplementation on the health and productivity of piglets. Veterinary record, 168, 188. doi: 10.1136/vr.c7033.

Streyl, K., Carlstron, J., Dantos, E., Mendoza, R., Islas, J.A., \& Bhushan, C. (2015). Field Evaluation of the Effectiveness of an Oral Toltrazuril and Iron Combination (Baycox ${ }^{\circledR}$ Iron) in Maintaining Weaning Weight by Preventing Coccidiosis and Anaemia in Neonatal Piglets, 114(1), 193-200. doi: 10.1007/s00436-015-4525-9.

Todoriuk, V.B., Hunchak, V.M., Gutyj, B.V., Gufriy, D.F., Hariv, I.I., Khomyk, R.I., \& Vasiv, R.O. (2018). Preclinical research of the experimental preparation "Ferosel T". Ukrainian Journal of Veterinary and Agricultural Sciences, 1(1), 3-9. doi: 10.15421/ujvas0101.

Tomyn, S., Shylin, S.I., Bykov, D., Ksenofontov, V., Gumienna-Kontecka, E., Bon, V., \& Fritsky, I.O. (2017) Indefinitely stable iron (IV) cage complexes formed in water by air oxidation. Nature Communications, 8, 1-8. doi: 10.1038/ncomms14099. 